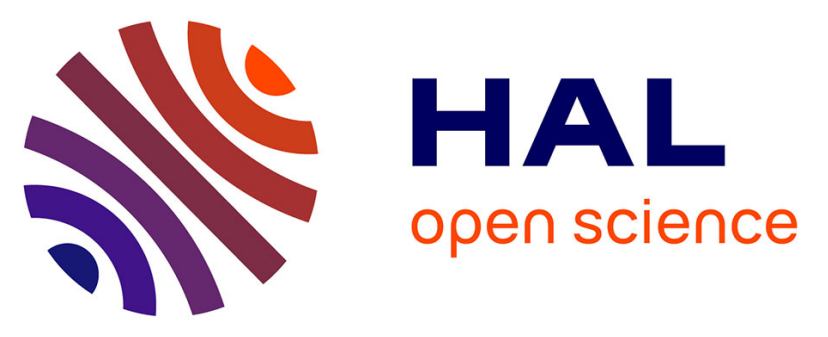

\title{
Decreasing fallow duration in tropical slash-and-burn agriculture alters soil macro-invertebrate diversity: A case study in southern French Guiana
}

Jean-Pierre Rossi, Léonide Celini, Philippe Mora, Jerome Mathieu, Emmanuel Lapied, Johanne Nahmani, Jean-François Ponge, Patrick Lavelle

\section{To cite this version:}

Jean-Pierre Rossi, Léonide Celini, Philippe Mora, Jerome Mathieu, Emmanuel Lapied, et al.. Decreasing fallow duration in tropical slash-and-burn agriculture alters soil macro-invertebrate diversity: A case study in southern French Guiana. Agriculture, Ecosystems and Environment, 2010, 135 (1-2), pp.148-154. 10.1016/j.agee.2009.08.012 . hal-00493992

\section{HAL Id: hal-00493992 https://hal.science/hal-00493992}

Submitted on 21 Jun 2010

HAL is a multi-disciplinary open access archive for the deposit and dissemination of scientific research documents, whether they are published or not. The documents may come from teaching and research institutions in France or abroad, or from public or private research centers.
L'archive ouverte pluridisciplinaire HAL, est destinée au dépôt et à la diffusion de documents scientifiques de niveau recherche, publiés ou non, émanant des établissements d'enseignement et de recherche français ou étrangers, des laboratoires publics ou privés. 
1 2 3 4

\title{
Decreasing fallow duration in tropical slash-and-burn agriculture alters soil macro-invertebrate diversity: A case study in southern French Guiana
}

\author{
J.P. Rossi*,a ${ }^{*}$ L. Celini ${ }^{\text {b }}$, P. Mora ${ }^{\mathrm{b}}$, J. Mathieu ${ }^{\mathrm{c}}$, E. Lapied ${ }^{\mathrm{d}}$, J. Nahmani ${ }^{\mathrm{e}}$, \\ J.-F. Pongef, P. Lavelle ${ }^{\mathrm{c}}$ \\ ${ }^{a}$ INRA, UMR1202 BIOGECO, F-33612 Cestas, France \\ ${ }^{b}$ Université Paris-XII, UMR 137 Biosol, F-94010 Créteil cedex, France \\ ${ }^{c}$ Université Paris-VI, UMR 137 BioSol, F-93143 Bondy Cedex, France \\ ${ }^{d}$ Norwegian University of Life Sciences, Department of Plant and Environmental \\ Sciences, Ås, Norway \\ ${ }^{e}$ CNRS, UMR 7146 LIEBE, Université de Metz, F-57070 Metz, France \\ ${ }^{f} M N H N, U M R$ 5176, F-91800 Brunoy, France
}

\begin{abstract}
In the humid tropics, slash-and-burn cultivation causes changes in the composition of soil biota communities. We investigated the soil macro-invertebrates (body length $\geq 2 \mathrm{~mm}$ ) in five sites, two at Maripasoula, an Aluku village along the Maroni river (French Guiana), with short fallow ( $\approx 8$ years), and the other three at Elahe, a Wayana village along the same river, with long fallow ( $\approx 25$ years). We report observed species richness, the corresponding estimates by bootstrap and its associated standard deviation. At both sites the cultivation led to impoverished communities. The overall observed species richness i.e. $\gamma$ diversity was ca. twice as larger in Elahe than in Maripasoula. The landscape at Maripasoula was dominated by highly disturbed areas with the direct consequence that local species richness relied on

\footnotetext{
${ }^{*}$ Corresponding author

Email address: Jean-Pierre.Rossi@pierroton.inra.fr (J.P. Rossi )
} 
colonization from an impoverished regional species pool. On the contrary, in Elahe, crops formed small patches scattered across a landscape essentially constituted of rich undisturbed or slightly disturbed forests hence higher $\gamma$ diversity. The proportion of rare species ranged from $44 \%$ to $54 \%$. We found 6 indicator species amongst which 5 were associated to the old secondary forest in Elahe and one, the earthworm Pontoscolex corethrurus was associated to crop fields in Maripasoula (short fallow system). Results are discussed in a landscape context in terms of conservation and management of soil macrofaunal diversity in agro-ecosystems.

Key words: Soil macrofauna, species richness, slash-and-burn agriculture, agriculture intensification, landscape, biodiversity.

\section{Introduction}

Soil invertebrates are key mediators of soil functions in agro-ecosystems.

They substantially affect many important processes that take place below-

4 ground like comminution and incorporation of litter into the soil, building and

5 maintenance of structural porosity and aggregation in soils through burrow-

6 ing, casting and nesting activities and control of microbial activities (Lavelle

7 et al., 2006, and references therein). Invertebrates therefore contribute to

8 the ecosystem services provided by soils and for this reason, they are in-

9 creasingly considered as a resource to be managed and protected. Amongst

10 soil biota, macrofauna (animals with body length $\geq 2 \mathrm{~mm}$ (Anderson and

${ }_{11}$ Ingram, 1993)) are dramatically affected by cultural practices and various

12 authors have discussed the utility of managing their populations to improve

13 the sustainability of soil fertility especially in countries or regions where farm- 
ers have limited access to mineral fertilizers (Matson et al., 1997; Brussaard et al., 2007; Rossi and Blanchart, 2005).

In the tropics, the traditional slash-and-burn system (shifting cultivation) consists of cutting the forest, burning the trees and settling familial agriculture for several years. Long fallow periods follow the cropping period and the regeneration of the vegetation combined with the recovery of soil fauna contribute to restore soil organic content and structure which in turn affect soil water and nutrient dynamics. These processes require a long fallow period (Grandisson, 1997). Unfortunately, the changes from a traditional to a permanent agriculture that accompany a population demographic growth generally lead to a decrease in the fallow duration (Fleury, 1998). Ultimately, the cropping period is followed by the establishment of permanent pastures used for cattle ranching instead of fallows. This is the case for huge surfaces of land in Brazil where these practices have a strong detrimental impact upon soil physical and chemical properties of the soil as well as diversity and activity of soil biota with dramatic impacts on the sustainability of agriculture (Mathieu et al., 2005).

In French Guiana, the demographic pressure threatens the long-lasting equilibrium between slash-and-burn agriculture and nature conservation, due to the progressive disappearance of shifting cultivation. In southern Guiana near the Suriname border, the duration of fallow in the slash-and-burn system has decreased from 15 to 7-8 years in the last 30 years (Topoliantz et al., 2006). The traditional shifting cultivation is still practised in that region by Amerindian communities and the duration of the fallow ranges from 15 to more than 100 years (Fleury, 1998). The aim of this study was to assess the 
impact of slash-and-burn cultivation upon the diversity of soil macrofauna in two agricultural systems that differed by the duration of the fallow period. We investigated a traditional shifting cultivation system in a small Wayana Amerindian village and an accelerated rotation cycle in a larger Aluku village where the demographic pressure is strong. Crops are mostly manioc (Manihot esculenta Cranz) i.e. cassava in both villages and the studied systems are good examples of traditional shifting cultivation (Wayana Amerindians) and change to permanent agriculture due to demographic pressure (Aluku village) (Grandisson, 1997).

\section{Materials and methods}

\subsection{Sites}

The present survey was carried out in southern French Guiana near the border between France and Suriname along the Maroni river. We investigated soil macrofauna diversity in agricultural fields of two communities, Wayanas (indians) and Alukus (maroons, of ancient African lineage). Wayana Amerindians are still using the traditional slash-and-burn system where short cropping periods (ca. 2-3 yr) alternate with long fallow periods $(\approx 25 \mathrm{yr})$. The fields (thereafter referred to as "abattis") are settled by cutting and burning forest plots and are planted with manioc which constitutes the basic food. Soils are not tilled and manioc cuttings (from previous crops) are planted after resprouting. Neither Wayanas nor Alukus use pesticides, herbicides or fertilizers. Alukus are using a similar system with the difference that cultivation does not exceed 1 year and fallows are shorter $(\approx 8$ yr on average). The length of the cultivation period depends on the soil fertility 
and the spontaneous regrowth of vegetation (Topoliantz et al., 2006).

Ameridian village of Elahe (long fallow). We sampled soil macrofauna in the Wayana (Amerindian) village of Elahe. This small village is situated on the Tampock river which is a subsidiary of Maroni $\left(3^{\circ} 26^{\prime} \mathrm{N}, 53^{\circ} 59^{\prime} \mathrm{W}\right)$. Three contrasted situations were investigated. A field that had been cut, burnt and cultivated by an Indian family 3 yrs before this study (EA). This field was located next to a secondary forest and was itself a secondary forest before its cultivation. It was sampled in July 1999. We sampled an old secondary forest (EF) located nearby EA (ca. $100 \mathrm{~m}$ ). The old secondary forest showed woody species typical of mature forests (e.g. Astrocaryum sciophilum (Miq.) Pulle, and Dicorynia guianensis Amsh. (Poncy et al., 2001) which indicated that it had been left untouched for at least 100 years. The plot located in the secondary forest was resampled in May 2000 after it had been cut and burnt in December 1999 for cultivation (EB).

Aluku village of Maripasoula (short fallow). The second site is located along the Maroni river $\left(3^{\circ} 39^{\prime} \mathrm{N}, 54^{\circ} 2^{\prime} \mathrm{W}\right)$ near the village of Maripasoula, ca. 25 $\mathrm{km}$ downstream of the first study site. Maripasoula is a large village (pop 1200 in 1999) mostly inhabited by Aluku people. The increase in population density during the last 3 decades led to a decrease in the surface of cultivable land and the subsequent decrease of fallow duration (Fleury, 1998). We sampled a 1-yr old abattis (MA) at the end of the crop period. It had been opened by an Aluku family by cutting and burning an 8-yr-old woody fallow referred to as MF. MF was characterized by pioneer woody species such as Cecropia latiloba Miq. and Inga capitata Desv. Both MA and MF plots were sampled in July 1999. The MF plot was intended to be burnt in December 
1999 and we planned to resampled in May 2000 but unfortunately the Aluku family did not burn it as expected.

The mean annual temperature is $26^{\circ} \mathrm{C}$ and the mean annual rainfall is $2000 \mathrm{~mm}$. There is a main dry season from September to December and a shorter one between March and April. Sampled soils are sandy Oxisols at pH of 5 and 4.7 on average in Maripasoula and Elahe, respectively (Topoliantz et al., 2006). The average total $\mathrm{C}$ content was 24.6, 22.5, 25.8, 19.1 and 18.6 $\mathrm{g} \mathrm{kg}^{-1}$ while the total $\mathrm{N}$ content was $1.65,1.48,1.78,1.39$ and $1.35 \mathrm{~g} \mathrm{~kg}^{-1}$ the in plots MA, MF, EA, EF and EB respectively (data from Table 1 in Topoliantz et al., 2006). Other physico-chemical features of the soils at the study sites are available in Topoliantz et al. (2006).

\subsection{Sampling}

We used the Tropical Soil Biology and Fertility (TSBF) procedure (Anderson and Ingram, 1993). Sampling units consisted of $25 \mathrm{~cm} \times 25 \mathrm{~cm}$ by $30 \mathrm{~cm}$ deep soil monoliths. As recommended in the TSBF procedure, we used 10 monoliths per transect and carried out 3 transects per plot (i.e. 30 samples per plots). The distance seperating monoliths was $5 \mathrm{~m}$ and transects were $20 \mathrm{~m}$ distant from each other. The litter was collected at each sampling point and a trench was then dug to a depth of $30 \mathrm{~cm}$ around the $25 \times 25$ $\mathrm{cm}^{2}$ area to get a soil monolith. Macroinvertebrates from soil and litter were hand-sorted and preserved in $4 \%$ formalin solution. Invertebrates were later counted and identified in the laboratory. We grouped specimens in morphospecies and identifed most of them with the help of different taxonomists. We excluded larvae from the statistical analyses because they were partially redundant with adults found in the same samples. Overall, our estimation 
of species richness is therefore underestimated.

\subsection{Data analysis}

\subsubsection{Community structure}

Principal Coordinate Analysis (PCoA). The first step of data analysis consisted of a Principal Coordinate Analysis (PCoA) of the raw data set (sitespecies abundances). This multivariate analysis is fully described in Legendre and Legendre (1998). It was first proposed by Gower (1966) and consists of the Euclidean representation of a set of objects described by any similarity or distance coefficients. We used PCoA in order to produce a general representation of our soil fauna samples and to examine to which extent they differed according to sites and land-use types. One advantage of this analysis is that the user can select the most appropriate distance or similarity index given the data at hand, which is not the case in more classical multivariate analyses e.g. PCA or CoA. We used the Bray-Curtis index (Legendre and Legendre, 1998, p. 287). The coefficient was computed using the R software (R Development Core Team, 2008) and the labdsv package (Roberts, 2007). The PCoA was done using the ade4 package (Chessel et al., 2004). The significance of PCoA axes were assessed by means of a bootstrap procedure based on 1000 randomizations (Pillar, 1999).

Species indicator value: IndVal. Because the PCoA is based on the diagonalization of a distance/similarity matrix there is no direct link between factorial axes and original descriptors (i.e. macrofauna species). We thus examined the presence of species associated to one or more samples or sites by means of a specific method, the IndVal value (Dufrêne and Legendre, 1997). Indi- 
cator species are species mostly present in one of the groups to be compared, while being mostly absent in other groups. Dufrêne and Legendre (1997) proposed to compute the IndVal index by combining two terms reflecting the specificity and the fidelity of a species for the samples corresponding to a certain land-use type. The specificity term is the mean abundance of a species $i$ in the samples of the land-use $j$ compared to all land-uses.

$$
A_{i j}=\text { Nindividuals }_{i j} / \text { Nindividuals }_{i}
$$

The fidelity term is the relative frequency of occurrence of species $i$ in samples of land-use $j$.

$$
B_{i j}=\text { Nsites }_{i j} / \text { Nsites }_{\bullet} j
$$

The indicator value of a given species is the product of specificity and fidelity terms in percent:

$$
\operatorname{IndVal} l_{i j}=A_{i j} \times B_{i j} \times 100
$$

The indicator value of a species $i$ for an array of sites is the largest value of IndVal ${ }_{i j}$ observed over all sites $j$. In this paper we adopted the threshold level of $25 \%$ for the index as suggested by Dufrêne and Legendre (1997), i.e. species $i$ is present in at least $50 \%$ of samples of land-use $j$ and its relative abundance in land-use $j$ is at least $50 \%$. We assessed the statistical significance of observed IndVal values by means of a permutation test (1000 randomizations) as proposed by Dufrêne and Legendre (1997).

Multi Response Permutation Procedure (MRPP). We tested the significance of community dissimilarities among land-uses by means of the Multi Response Permutation Procedure (MRPP) (Quinn and Keough, 2002). MRPP 
tests whether there is a significant difference between two or more groups of sampling units. The MRPP statistic $\delta$ is the overall weighted mean of withingroup means of pairwise dissimilarities among sampling units. The observed value is statistically tested by mean of a permutation test where sampling units and their associated pairwise distances are permuted $N$ times and $\delta$ is recalculated. The significance test is based on the proportion of permuted $\delta$ s that are less than the observed $\delta$. We used the Bray-Curtis distance to quantify the dissimilarities between land-uses. MRPP was computed using the vegan package (Oksanen et al., 2008).

\subsubsection{Species richness}

Samples were pooled to compute the observed bulk species richness for each land-use type. We used bootstrap procedure to determine a possible bias in the species richness estimator and to remove it from the observed value. For a given land-use, a randomized sample of $n=30$ sampling units was constituted by randomly sampling with replacement amongst the 30 original units and the observed cumulated species richness was computed. This was repeated $\mathrm{N}$ times and constituted the bootstrap sample. The bias was defined as the observed mean species richness minus the average of the $\mathrm{N}$ observed species richnesses (Manly, 1997). A corrected estimate of species richness was obtained by substracting the bias to the observed species richness. We approximated the standard error of the estimated species richness by the standard deviation of bootstrap estimates following Manly (1997, p. 36). Species rarity was measured as absolute and relative frequencies of singletons, i.e. species with at most 1 individual per sample. We also report another measure of rarity based on frequency of species: the number of unique species, 
i.e. species that occurred in only one sample. The observed species richnesses in the different land-uses were compared by mean of a one-factor analysis of variance. Because our data did not satisfy most of the assumptions of ANOVA we used the randomization test described by Manly (1997, p.117). The observed F statistic was tested by comparison with corresponding values in $N$ ANOVAS after randomization of raw data.

\section{Results}

\subsection{General statistics}

Soil macrofauna communities differed markedly amongst land-uses and between sites. The average macrofaunal density was higher in the secondary forest (EF) in Elahe followed by the abbatis in Maripasoula (MA) and it was lowest in the recently burnt secondary forest in Elahe (EB)(Table 1). The observed species richness varied accordingly with a total of 121 species in the secondary forest in Elahe (EF) and values ranging from 22 to 54 species in the other plots. Corresponding bias-corrected values estimated from bootstrap were somewhat higher (Table 1) but between-site ranking did not change at all (there is a linear relationship between original and corrected values). The number of singletons and unique species respectively ranged from $44 \%$ to 54 $\%$ and $55 \%$ to $72 \%$, respectively, and was fairly homogeneous amongst sites (Table 1). A grand total of $S=186$ species was recorded (all sites pooled) amongst which $42(22.6 \%)$ were common to Elahe and Maripasoula (shared species). One hundred and twelve (60.2\%) species were encountered in the site of Elahe whereas $32(17.2 \%)$ species were only recorded in Maripasoula. 


\subsection{Community structure}

First and second eigenvalues of PCoA significantly differed from those stemming from $N=1000$ randomizations and accounted for $20.7 \%$ and $16 \%$ of the total inertia, respectively. Axis 1 clearly reflected changes in macrofauna community structure according to the type of agriculture: Maripasoula plots (slash-and-burn agriculture with short fallow periods) are opposed to Elahe plots (traditional shifting agriculture) along Axis 1 (Fig. 1). EA, the abbatis from the Elahe village was intermediate. Interestingly, plots EA, EF and EB were clearly different and much more heterogeneous than MA and MF. Within-plot heterogeneity was graphically represented by the scattering of samples around each centre of inertia. Axis 2 mainly reflected within site variability and did not discriminate land-uses. MRPP (1000 randomizations) showed that community dissimilarity among the five land-uses was highly significant $(p<0.001)$.

\subsection{Species richness within and between sites}

A total of 145 species were found in Elahe amongst which 121 were recorded in the secondary forest (EF) i.e. $83 \%$ of the total (Table 2). The abattis (EA) hosted 45 species among which $17 \%$ were shared with EF. The recently burnt forest (EB) harboured a total of 22 species, ca. $15 \%$ of the total richness (Table 2). The number of exclusive species i.e. those species that were found in only one land-use was 93, 20 and 12 for EF, EA and EB, respectively. The proportion of shared species between EB and both EF and EA was low and ranged from $6.7 \%$ to $9.8 \%$ (Table 2). In the short fallow system (Maripasoula) the total species richness (all sites pooled) was 77 . The woody fallow that served as reference hosted 54 species (70\% of the total) 
while the abattis hosted 41 species ( $53 \%$ of the total) (Table 3 ). The proportion of shared species was $28 \%$ (Table 3) which was higher than Elahe (Table 2). The observed species richness significantly differed among land-uses as indicated by the ANOVA test based on 1000 randomizations $(p<0.001)$.

\subsection{Indicator species}

Six morphospecies showed IndVal values $\geq 25 \%$ and significant associated probabilities at $\alpha=0.05$ : two earthworms, two centipedes, a termite and a bristletail (Table 4). Five of these were associated to the old secondary forest (traditional slash-and-burn shifting agriculture) while one earthworm species, Pontoscolex corethrurus, was indicator of the abattis in the short fallow system in the Aluku village of Maripasoula.

\section{Discussion}

\subsection{Forest logging and fire}

Forest clearing and burning had a strong impact upon soil macrofauna species richness in Elahe. Soil macrofauna communities were dramatically impoverished soon after fire (plot $\mathrm{AB}$ ) and remained strongly affected three years after crop establishment (plot EA). Tree harvesting is known to affect the composition of soil faunal communities as well as food web structure in various ways (Bengtsson et al., 1997). One direct and strong impact is the change in soil climatic conditions (temperature, moisture) that is associated to the direct exposure of soil to solar radiation (Matlack, 1993). These effects are magnified by fire associated with forest logging. During fire, the temperature of the surface soil can exceed $400^{\circ} \mathrm{C}$ (Gimeno-García et al., 2004) with 
important consequences upon soil dwelling organisms and most notably nonmobile species that inhabit litter layers and/or upper soil strata (Mathieu et al., 2005; Abbott et al., 2003). Fire also indirectly affects soil fauna by destroying epigeic microhabitats like decaying wood, fine twigs, dead plant stems and leaves that serve as trophic resources or habitat for numerous species (Mathieu et al., 2005).

Not surprisingly, the species pool observed in the recently burnt plot EB was constituted either by species that withstand forest logging and burning or by colonisers originating from adjacent areas.

After a few years of cropping, the species richness had increased but remained low (plot EA) and ca. half the species richness of the abattis was constituted by species also present in the forest (Table 2). One may hypothesize that these species are eurytopic (species with large niche breadth) that can withstand the environmental conditions that prevail in crop plots. These results are fully in accordance with data collected in eastern Amazonia (Brazil) (Mathieu et al., 2005).

Interestingly, forest clearing and the set up of manioc crop has a lower impact on the observed richness in the region of Maripasoula where crop rotation is more rapid. The abattis (MA) and the woody fallow (MF) share more species than corresponding plots in Elahe (EA and EF): one reason for this is that the plots that are logged and burnt in Maripasoula are woody fallows ca. 7-8 yr-old and by no means old growth forests as in Elahe. The species richness of such plots is low and roughly comparable to what is observed in the abattis in the traditional slash-and-burn system in the native Amerindian area of Elahe. These results indicate that agricultural intensi- 
fication leads to impoverishment of species richness and homogenization of soil macrofaunal communities.

All but one species that were found to be indicators were associated to the old secondary forest in Elahe (EF). Given huge environmental differences that exist between the forest and other land-uses, forest specialists could be expected to have high IndVal values. This index encapsulates two contrasted and complementary information, specificity and fidelity. Soil macroorganisms generally display a highly aggregated spatial distribution (Ettema and Wardle, 2002) and this is even more marked in the case of social insects like termites or ants. This leads to high variance of abundance data and may cause low values of the fidelity term $B_{i j}$ and subsequently low and/or not-significant IndVal index (Nahmani et al., 2006). Apart from specialist species from the secondary forest, only one species was associated to crops with short fallow periods, the pantropical endogeic earthworm P. corethrurus (Oligochaeta, Glossoscolecidae). This peregrine species has been dispersed worldwide by man and is probably indigenous to the Guianas plateau in South America (Righi, 1984). This species exhibits a very good aptitude to withstand soil disturbance and scarcity of organic matter and is abundant in open areas over a wide range of tropical regions (Lavelle et al., 1987). $P$. corethrurus has been shown to have the capacity to invade Amazonian pastures and to cause soil degradation through physical compaction of the soil surface (Chauvel et al., 1999). However, other studies showed that it can incorporate charcoal to the topsoil thereby increasing its humus content of the topsoil by adding finely powdered black carbon (Ponge et al., 2006; Topoliantz and Ponge, 2003, 2005). 


\subsection{Landscape context and species diversity}

Our sampled soils differed in terms of physico-chemical parameters (e.g. total $\mathrm{C}$ content) and these differences can be explained by land management practices among which fallow duration. Land management can have direct effects upon soil biodiversity as well as indirect effects through changes in soil parameters like or $\mathrm{C}$ or $\mathrm{N}$ content. Both direct and indirect effects convey land-use impacts on soil biodiversity. In that context, our plots can be compared although our data do not allow unravelling such direct and indirect effects.

Comparing Elahe and Maripasoula sites allows us to discuss the effects of the reduction of fallow duration upon $\gamma$, i.e. regional diversity. The impact of reduced fallow on the pooled richness was huge (145 versus 77 species in Elahe and Maripasoula, respectively). The main difference between these species pools is due to the low richness of the woody fallow (MF) in Maripasoula as compared to the old secondary forest (EF) in Elahe. The woody fallow is the typical habitat that is cut and burnt before crop settlement in the reduced fallow system. There is no secondary forest nor older fallow left in the region of Maripasoula where all areas accessible by foot or by canoe have been and are still used for cultivation (Topoliantz et al., 2006). On the other hand, abattis are similar in Elahe and Maripasoula in terms of richness (roughly 40 to 45 species) although the proportion of shared species is low $(\approx 21 \%)$.

Various mechanisms contribute to link $\alpha$ diversity to neighbouring landscape configuration (Dunning et al., 1992; Rossi and van Halder, in press). Species richness in the abattis could be affected by the neighbouring speciesrich secondary forest or by woody fallows through the so-called "vicinism" or 
"mass" effect (Zonneveld, 1995) whereby a flow of individuals originates from species rich habitat and allows the presence of species in neighbouring habitats where they are not self-maintaining (Shmida and Wilson, 1985). This corresponds to the "spillover effect" by which species can be maintained in unsuitable habitat patches in the framework of source-sink dynamics (Holt, 1997). In the context of accelerated crop rotation, the amount of land covered by pristine habitats is very low if not zero. In the site of Elahe, the situation is inverse, crops constituting a habitat distributed as small patches scattered across a landscape essentially constituted of rich undisturbed or slightly disturbed forests. In highly anthropised landscapes, the overall proportion of species with high capacity to colonize abattis is larger and the landscape contex tends to favour a rapid colonization of newly settled fields. This is not the case in the Amerindian region where abattis are hardly spatially connected.

\subsection{The importance of rare species}

We defined rare species as species collected as single individuals, singletons. All studied sites exhibited roughly $50 \%$ of singletons and an even larger proportion of unique species. Such high values were reported e.g. for insect communities associated to tropical trees (Novotný and Basset, 2000) and soil macrofauna in Amazonian pastures (Rossi et al., 2006). Rarity can be a problem during data analysis and various indices have been proposed to correct estimates of species richness and shared species (Colwell and Coddington, 1994; Chao et al., 2005). In this study we used a bootstrap correction of species richness estimates which led to corrected estimates that were linearly correlated to observed species richnesses. This indicated that our perception of between-site similarity in terms of species richness were correct even when 
solely based on raw data.

Statistics aside, rare species raise the question why are they so numerous. First, rare species could be species that were inadequately sampled and this must be considered with caution. Indeed, soils are highly variable habitats with various nested sources of spatial heterogeneity that affected species distribution and hence short-scale diversity patterns (Mathieu et al., 2009). The problem of sampling deficiency in estimating biodiversity in soils is discussed elsewhere (Rossi et al., 2006) and could possibly be responsible for a certain proportion of our rare species. It must be also noted that the TSBF sampling protocol may not be optimal for certain type of organisms and notably litter inhabiting species. Other sampling methods like Winkler bags may also be used (Smith et al., 2008) while specific strategies have been developped for social insects (termites) (Jones and Eggleton, 2000). On the other hand, the "spillover effect" could lead to the presence of rare species simply because they are transient species i.e. species that cannot maintain in one habitat but originates from a neighbouring habitat that acts as a permanent source. Distinguishing transient species is a very difficult task (Novotný and Basset, 2000) that would require a huge amount of additional field data (and directional activity traps) in our case. However, this is the only way to refine our estimates of species richness while controlling for close neighbourhood effects and therefore assessing landscape effects upon crop field species richness.

4.4. Conservation and management of soil macrofaunal diversity in agroecosystems

It is broadly acknowledged that the conservation of soil macrofauna in agroecosystems is an important aspect of sustainable agriculture (Brussaard 
et al., 2007) but the spatial facet of that question have not yet received the attention it requires (but see Tscharntke et al., 2005). The landscape at Maripasoula is dominated by highly disturbed areas and the direct consequence is an erosion of $\gamma$ diversity. Local species richness thus rely on colonization from impoverished regional species pool. Swift et al. (2004) argue that the management of biodiversity in agricultural context is more effective at the landscape scale than at the local plot scale where strictly utilitarian options prevail. Following this line of reasoning, and given that most forest species are unlikely to maintain themselves within abattis, the management of $\gamma$ diversity may be based on the maintenance of fallow plots of a large range of age and not only of pristine ecosystems. It is additionally important to consider the spatial arrangement of these plots across the landscape. They act as source of colonisers for newly abandoned field crops and as such their spatial location may be of prime importance. The dispersal abilities of most soil invertebrates are not very well documented but are certainly limited for many species and this reinforces the importance of the distribution of the source of colonisers within agricultural landscapes.

\section{Acknowledgements}

We are greatly indebted Gabriel Fossé (Maripasoula) who guided us through the forest and the rivers, tremendously contributed to field work and had the role of interpreter when we were at the village of Elahe. We also want to thank everybody at Elahe and Maripasoula for their warm welcome and giving access to their abbatis. We thank Céline Houdin, Périne Lavelle, Jocelyne Roman, Corinne Rouland and Stéphanie Topoliantz who helped in 
the fieldwork. We are indebted to Guy Pallaud (ONF, Maripasoula) for his help and interest in this project when we stayed in Maripasoula in 2000. This work was conducted in the framework of the SOFT programme "Effets des pratiques culturales traditionnelles sur la fertilité des sols et la régénération de la forêt du sud de la Guyane" coordinated by J. M. Betsch et S. Bahuchet and funded by the French Ministry of the Environment. We thank two anonymous reviewers for their useful comments on an earlier version of the manuscript

\section{References}

Abbott, I., Burbidge, T., Strehlow, K., Mellican, A., Wills, A., 2003. Logging and burning impacts on cockroaches, crickets and grasshoppers, and spiders in Jarrah forest, Western Australia. Forest. Ecol. Manage. 174, 383-399.

Anderson, J., Ingram, J., 1993. Tropical Soil Biology and Fertility: a Handbook of Methods. CAB International, Oxford.

Bengtsson, J., Persson, T., Lundkvist, H., 1997. Long-term effects of logging residue addition and removal on macroarthropods and enchytraeids. J. Appl. Ecol. 34, 1014-1022.

Brussaard, L., de Ruiter, P. C., Brown, G. G., 2007. Soil biodiversity for agricultural sustainability. Agric. Ecosyst. Environ. 121, 233-244.

Chao, A., Chazdon, R. L., Colwell, R. K., Shen, T.-J., 2005. A new statistical approach for assessing similarity of species composition with incidence and abundance data. Ecol. Lett. 8, 148-159. 
Chauvel, A., Grimaldi, M., Barros, E., Blanchart, E., Desjardins, T., Sarrazin, M., Lavelle, P., 1999. Pasture damage by an Amazonian earthworm. Nature 398, 32-33.

Chessel, D., Dufour, A.-B., Thioulouse, J., 2004. The ade4 package-I: Onetable methods. R News 4, 5-10.

Colwell, R. K., Coddington, J. A., 1994. Estimating terrestrial biodiversity through extrapolation. Philos. Trans. R. Soc. Lond. B 345, 101-118.

Dufrêne, M., Legendre, P., 1997. Species assemblages and indicator species: the need for a flexible asymetrical approach. Ecol. Monogr. 67, 345-366.

Dunning, J. B., Danielson, B. J., Pulliam, H. R., 1992. Ecological processes that affect populations in complex landscapes. Oikos 65, 169-175.

Ettema, C., Wardle, D., 2002. Spatial soil ecology. Trend. Ecol. Evol. 17, $177-183$.

Fleury, M., 1998. Les populations du Haut-Maroni et le projet du Parc National de la Guyane. JATBA 40, 577-610.

Gimeno-García, E., Andreu, V., Rubio, J., 2004. Spatial patterns of soil temperatures during experimental fires. Geoderma 118, 17-38.

Gower, J., 1966. Some distance properties of latent root and vector methods used in multivariate analysis. Biometrika 53, 325-338.

Grandisson, M., 1997. Diagnostic de la reproductibilité de la fertilité dans les abattis de la région ouest-Guyane: étude des stratégies de gestion et analyse des trajectoires d'évolution des composantes de la fertilité en fonction 
du milieu et des modes de mise en valeur. Ph. thesis, Université AntillesGuyane, Cayenne, France.

Holt, R. D., 1997. From metapopulation dynamics to community structure - some consequences of spatial heterogeneity In: Hanski, I. A., Gilpin, M. E. (Eds.), Metapopulation Biology - Ecology, Genetics, and Evolution. Academic Press, San Diego, pp. 149-164.

Jones, D. T., Eggleton, P., 2000. Sampling termite assemblages in tropical forests: testing a rapid biodiversity assessment protocol. J. Appl. Ecol. 37, $191-203$.

Lavelle, P., Barois, I., Cruz, C., Hernandez, A., Pineda, A., Rangel, P., 1987. Adaptative strategies of Pontoscolex corethrurus (Glossoscolecidæ, Oligochæta), a peregrine geophagous earthworm of the humid tropics. Biol. Fert. Soils 5, 188-194.

Lavelle, P., Decaëns, T., Aubert, M., Barot, S., Blouin, M., Bureau, F., Margerie, P., Mora, P., Rossi, J.-P., 2006. Soil invertebrates and ecosystem services. Eur. J. Soil Biol. 42, S3-S15.

Legendre, P., Legendre, L., 1998. Numerical Ecology, Second English Edition. Elsevier, Amsterdam.

Manly, B., 1997. Randomization and Monte Carlo methods in Biology. Chapman \& Hall, London.

Mathieu, J., Grimaldi, M., Rouland, C., Lavelle, P., Desjardin, T., Rossi, J.- 
P., 2009. Variations in soil macrofauna biodiversity with spatial patterns of grasses in Amazonian pastures. Soil Biol. Biochem. 41, 586-593.

Mathieu, J., Rossi, J.-P., Grimaldi, M., P., M., Lavelle, P., Rouland, C., 2004. A multi-scale study of soil macrofauna biodiversity in Amazonian pastures. Biol. Fert. Soils 40, 300-305.

Mathieu, J., Rossi, J.-P., Mora, P., Lavelle, P., Martins, P. F. D. S., Rouland, C., Grimaldi, M., 2005. Recovery of soil macrofauna communities after forest clearance in Eastern Amazonia, Brazil. Conserv. Biol. 19, 15981605.

Matlack, G. R., 1993. Microenvironment variation within and among forest edge sites in the eastern United States. Biol. Conserv. 66, 185-194.

Matson, P. A., Parton, W. J., Power, A. G., Swift, M. J., 1997. Agricultural intensification and ecosystem properties. Science 277, 504-509.

Nahmani, J., Lavelle, P., Rossi, J.-P., 2006. Does changing the taxonomical resolution alter the value of soil macroinvertebrate as bioindicators of metal pollution? Soil Biol. Biochem. 38, 385-396.

Novotný, V., Basset, Y., 2000. Rare species in communities of tropical insect herbivores: pondering the mystery of singletons. Oikos 89, 564-572.

Oksanen, J., Kindt, R., Legendre, P., O’Hara, B., Simpson, G., Stevens, M., Wagner, H., 2008. vegan: Community Ecology Package. R package version 1.13-1. http://vegan.r-forge.r-project.org/ 
Pillar, V. D., 1999. The bootstrapped ordination re-examined. J. Veg. Sci. 10, 895-902.

Poncy, O., Sabatier, D., Prévost, M.F., Hardy, I., 2001. The lowland high rainforest: structure and tree species diversity. In: Bongers, F., CharlesDominique, P., Forget, P.M., Théry, M. (Eds.), Nouragues: Dynamics and Plant-Animal Interactions in a Neotropical Rainforest. Academic Press, San Diego, pp. 149-164.

Ponge, J., Topoliantz, S., Ballof, S., Rossi, J.-P., Lavelle, P., Betsch, J., Gaucher, P., 2006. Ingestion of charcoal by the amazonian earthworm Pontoscolex corethrurus: a potential for tropical soil fertility. Soil Biol. Biochem. 38, 2008-2009.

Quinn, G., Keough, M., 2002. Experimental Design and Data Analysis for Biologists. Cambridge University Press, Cambridge.

R Development Core Team, 2008. R: A Language and Environment for Statistical Computing. R Foundation for Statistical Computing, Vienna, Austria. ISBN 3-900051-07-0, URL http://www.R-project.org.

Righi, G., 1984. Pontoscolex (Oligochæta, Glossoscolecidæ): a new evaluation. Stud. Neotrop. Fauna Environ. 19, 159-177.

Roberts, D., 2007. labdsv: Ordination and Multivariate Analysis for Ecology. $\mathrm{R}$ package version 1.3-1. http://ecology.msu.montana.edu/labdsv/R

Rossi, J.-P., Blanchart, E., 2005. Seasonal and land-use induced variations 
of soil macrofauna composition in the Western Ghats (South India). Soil Biol. Biochem. 37, 1093-1104.

Rossi, J.-P., van Halder, I., in press. Towards indicators of butterfly biodiversity based on a multiscale landscape description. Ecol. Indic., DOI: 10.1016/j.ecolind.2009.07.016.

Rossi, J.-P., Mathieu, J., Cooper, M., Grimaldi, M., 2006. Soil macrofaunal biodiversity in Amazonian pastures: matching sampling with patterns. Soil Biol. Biochem. 38, 2178-2187.

Shmida, A., Wilson, M. V., 1985. Biological determinants of species diversity. J. Biogeogr. 12, 1-20.

Smith, J., Potts, S., Eggleton, P., 2008. Evaluating the efficiency of sampling methods in assessing soil macrofauna communities in arable systems. Eur. J. Soil Biol. 44, 271-276.

Swift, M. J., Izac, A. M. N., van Noordwijk, M., 2004. Biodiversity and ecosystem services in agricultural landscapes-are we asking the right questions? Agric. Ecosyst. Environ. 104, 113-134.

Topoliantz, S., Ponge, J. F., 2003. Burrowing activity of the geophagous earthworm Pontoscolex corethrurus (Oligochaeta: Glossoscolecidae) in the presence of charcoal. Appl. Soil Ecol. 23, 267-271.

Topoliantz, S., Ponge, J. F., 2005. Charcoal consumption and casting activity by Pontoscolex corethrurus (Glossoscolecidae). Appl. Soil Ecol. 28, 217224 . 
${ }_{528}$ Topoliantz, S., Ponge, J. F., Lavelle, P., 2006. Humus components and bio${ }_{529}$ genic structures under tropical slash-and-burn agriculture. Eur. J. Soil Sci. $530 \quad 57,269-278$.

531 Tscharntke, T., Klein, A. M., Kruess, A., Steffan-Dewenter, I., Thies, C., 532 2005. Landscape perspectives on agricultural intensification and biodiver533 sity - ecosystem service management. Ecol. Lett. 8, 857-874.

${ }_{534}$ Zonneveld, I. S., 1995. Vicinism and mass effect. J. Veg. Sci. 6, 441-444. 


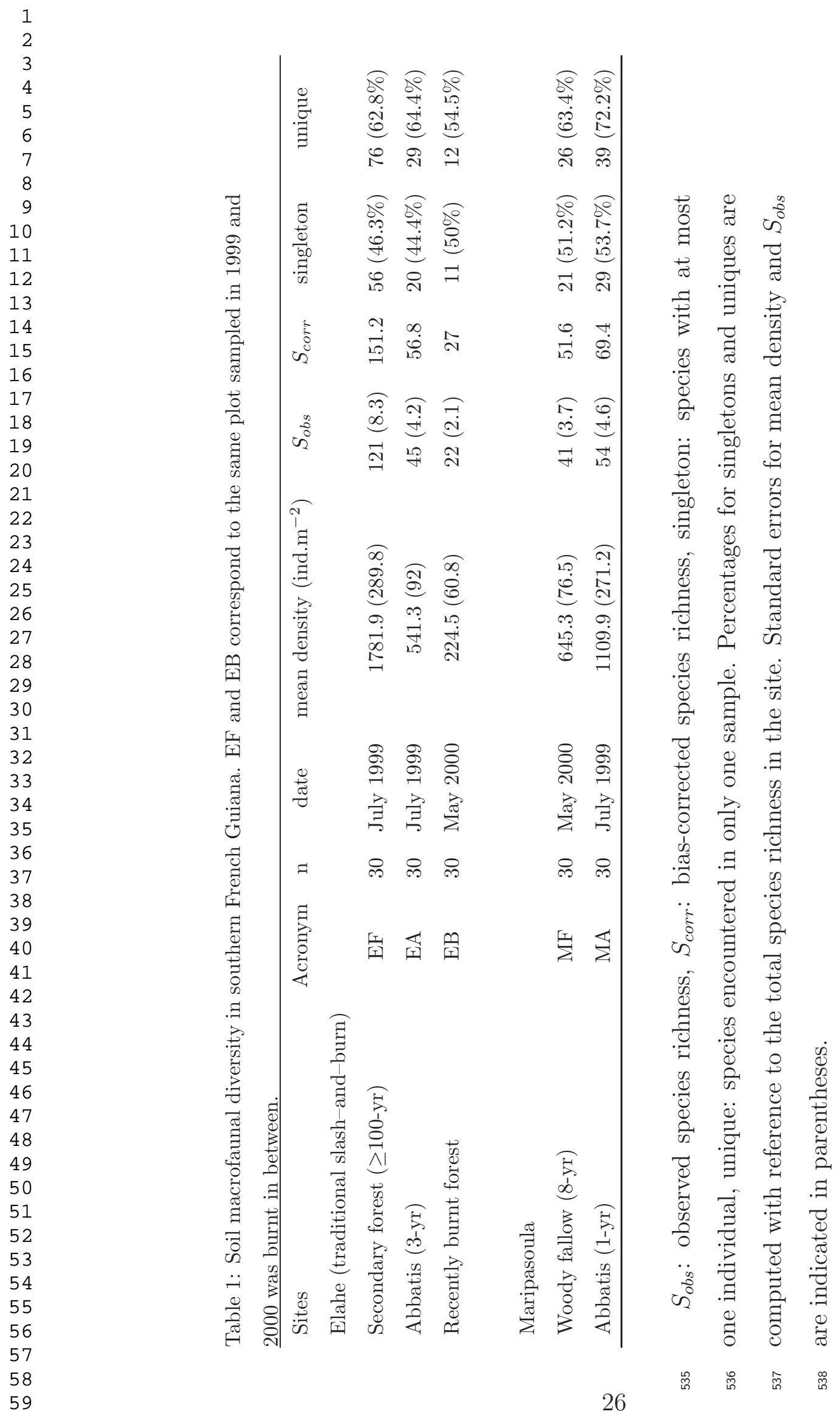

60

61

62

63 
Table 2: Observed species richness and shared species of soil macrofauna in different landuses in a traditional Amerindian slash-and-burn system (region of Elahe, southern French Guiana).

\begin{tabular}{l|ccc}
$S_{\bullet}=145$ & $\mathrm{EF}$ & $\mathrm{EA}$ & $\mathrm{EB}$ \\
\hline $\mathrm{EF}$ & $121(83.4 \%)$ & $24(142)$ & $9(134)$ \\
$\mathrm{EA}$ & $17 \%$ & $45(31 \%)$ & $6(61)$ \\
$\mathrm{EB}$ & $6.7 \%$ & $9.8 \%$ & $22(15.2 \%)$
\end{tabular}

539 EF: Secondary forest, EA: Abbatis, EB: recently burnt forest, $S_{\bullet}$ : total species richness (all sites pooled). On diagonal: observed species richness and corresponding ratio to the total number of species (in parentheses). Above diagonal: absolute number of species shared by site pairs and total number of species collected in site pairs. Below diagonal: ratio of the number of shared species to the total number of species in site pairs. 
Table 3: Observed species richness and shared species of soil macrofauna in different land-uses in a short-fallow system (region of Maripasoula, southern French Guiana).

\begin{tabular}{l|cc}
$S .=77$ & MF & MA \\
\hline MF & $54(70.1 \%)$ & $21(74)$ \\
MA & $28.4 \%$ & $41(53.2 \%)$
\end{tabular}

${ }_{545}$ MF: Secondary forest, MA: Abbatis, $S_{\bullet}$ : total species richness (all sites 546 pooled). On diagonal: observed species richness and corresponding ratio 547 to the total number of species (in parentheses). Above diagonal: absolute 548 number of species shared by site pairs and total number of species collected 549 in site pairs. Below diagonal: ratio of the number of shared species to the 550 total number of species in site pairs. 
Table 4: Soil macrofaunal indicator species in agricultural landscapes in southern French Guiana. IndVal values were tested using permutation tests $(n=1000)$. See text for definitions and Table 1 for land-use acronyms.

\begin{tabular}{lcccccc}
\hline Species & group & Specificity & Fidelity & IndVal & $p$ & Land-use \\
Pontoscolex corethrurus & Oligochaeta & 0.38 & 0.97 & 36.9 & 0.001 & MA \\
morphospecies 1 & Diplura & 0.92 & 0.33 & 30.4 & 0.001 & EF \\
morphospecies 2 & Isoptera & 0.84 & 0.57 & 47.9 & 0.001 & EF \\
morphospecies 3 & Chilopoda & 0.79 & 0.43 & 34 & 0.001 & EF \\
morphospecies 4 & Chilopoda & 0.68 & 0.43 & 29.2 & 0.001 & EF \\
morphospecies 1 & Lumbricida & 0.51 & 0.67 & 34.2 & 0.001 & EF \\
\hline
\end{tabular}


551

552

553

559 560

\section{Figure captions}

\section{Figure 1}

Principal Coordinates Analysis (PCoA) of soil macrofaunal communities in different land-uses in southern French Guiana. Projection of site scores in the plane defined by Axes 1 (horizontal) and 2 (vertical). Labels are placed at the centre of gravity of each site and are linked to each sample of the corresponding site. See Table 1 for site codes. 


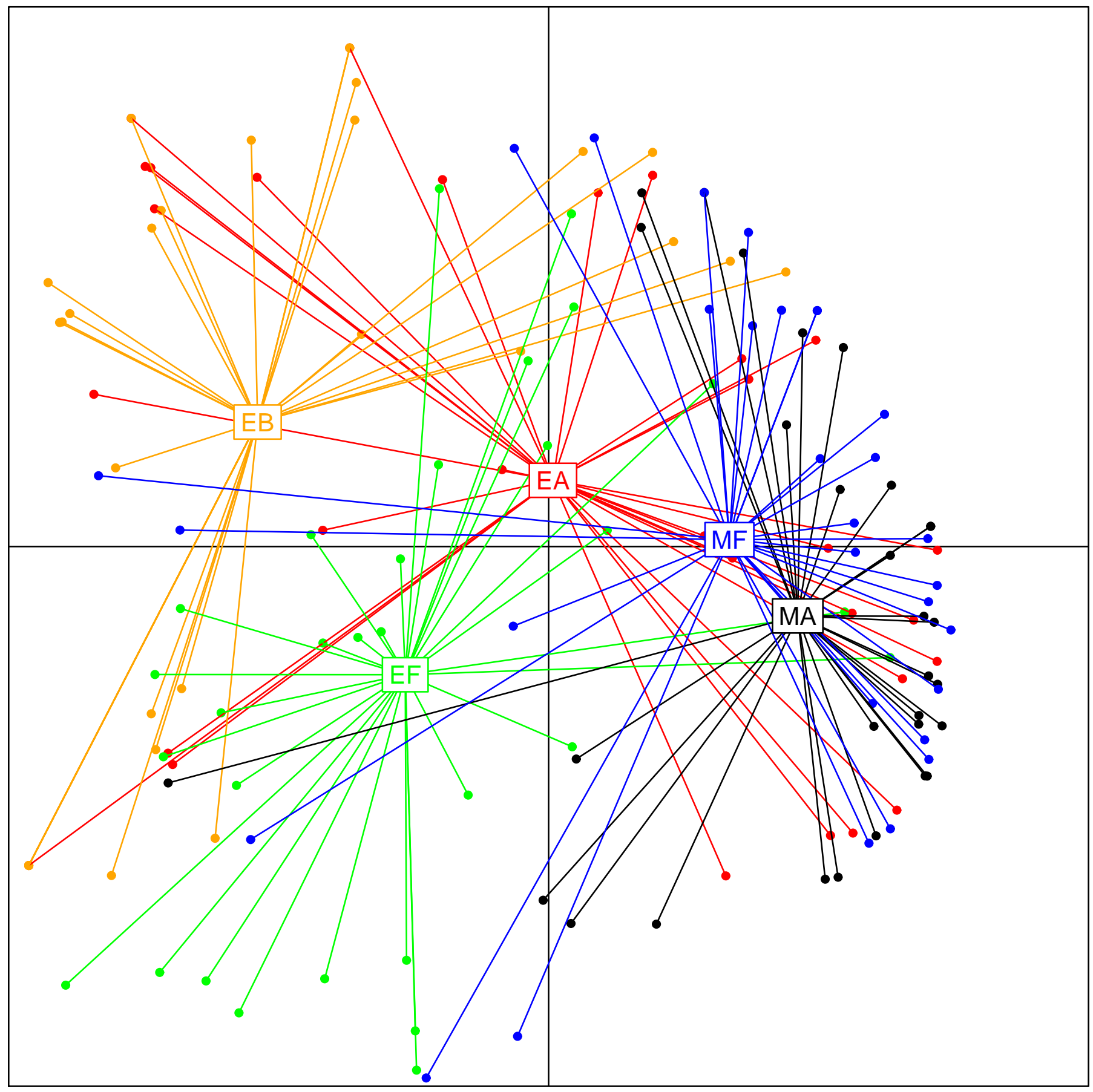

